\title{
Gene patents in the US - focusing on what really matters
}

\author{
Allison W Dobson ${ }^{1 *}$ and James P Evans ${ }^{2}$
}

\begin{abstract}
With new technologies, concerns about gene patent claims regarding isolated DNA are becoming less relevant, but broad method claims could be more problematic.

Keywords Gene patent, sequencing, isolated DNA, method, abstract, diagnostics, obviousness, Myriad, Prometheus, Classen
\end{abstract}

As we move into the era of exome and whole-genome sequencing and witness a concurrent explosion in genomic data, concerns about related biotechnology patents must also shift accordingly. These are complex issues that are in a state of flux, and we find ourselves at an especially critical juncture given the US Supreme Court's recent treatment of several high-profile biotechnology cases. Here, we discuss recent developments in US patent law and the most pressing issues on the horizon, including pivotal issues surrounding the topic of patenting in genetics and biotechnology in the US. We particularly address some of the neglected or seemingly arcane points that nevertheless are critical to the researcher, medical practitioner, scientist, or indeed anyone seeking informed opinions about patent protection of new biotechnologies and genetic technologies. Striking the appropriate balance between intellectual property protection and public benefit is essential to promoting advances in the field.

The term 'gene patent' itself is ambiguous, and this term has been used loosely in the media to encompass a wide variety of patents related to genetics. Patents typically contain multiple claims in various forms, and each claim in a patent may stand or fall independently of the others. The subject matter claimed can be a tangible product (such as a DNA molecule) or a process indicated

*Correspondence: dobson.allison@gmail.com

16628 Ridge Run Ct. Clemmons, NC 27012, USA

Full list of author information is available at the end of the article by gerunds (for example, 'constructing,' 'connecting', or 'sequencing') that outline the steps of the method.

Both product and method claims are found in generelated patents. Understanding the different claims encompassed by the imprecise term 'gene patent' is critical to the proper interpretation and application of patent law as we seek to optimally promote the development of genetic medicine. Because patent law is complicated (see Box 1 for a brief summary), the popular media understandably tends to avoid going into such differences in their attempts to simplify headlines about the topic [1,2]. The Supreme Court has recently cast serious doubt on broad method claims related to genes - but not on product claims.

A claim directed to 'isolated DNA' covers a single type of molecule, such as a PCR product, usually referring to a specific DNA sequence. It does not cover the sequence itself, as many professionals seem to believe. Thus, the patent holder is legally entitled to exclude others from making or using only that isolated DNA, based on that particular claim. Depending on how the claim is worded, the court may interpret it to cover isolated molecules with additional sequences that flank the named sequence (such as in a purified plasmid or other vector), but under no circumstances should a claim to isolated DNA preempt others from using its corresponding sequence as it exists within genomic DNA. That is the whole point of using the word 'isolated' - to clarify that the natural occurrence of that sequence is not what is claimed in the patent, but rather the physical molecule.

For scientists and physicians, the critical question should be whether any given patent stands in the way of their work. Isolated DNA claims are becoming less relevant to medical diagnostics, because sequencing a patient's DNA with modern (next-generation) technology is unlikely to infringe any product claim directed to an isolated DNA molecule. Thus, in a new genomic era, it is appropriate to refocus on broad method claims that have greater potential to affect the practice of medicine and medical research.

\section{The Myriad case: why it is important and where it stands today}

As with many gene patents, the gene patent case Association for Molecular Pathology et al. v. USTPO et al. 


\section{Box 1. A US patent law primer}

US patent law requires that a number of different complex requirements be met before a patent is granted, and the validity of an issued patent may be challenged thereafter on any of the same grounds. The requirements are codified in sections 101, 102, 103, and 112 of USC Title 35, also known as the Patent Act. Section 101 addresses only what types of subject matter are eligible for patenting [5]; the other sections address issues of novelty, obviousness, and sufficiency of the accompanying descriptions for fully enabling others in the field to make and use the invention or discovery.

Historically, section 101 has been construed very broadly by the Supreme Court and the US Patent and Trademark Office to include 'anything under the sun made by man' and the other sections have been applied more stringently to filter out subject matter that is unsuitable for patenting (for example, products of nature and abstract concepts). The distinctions between the requirements of these four sections of the Patent Act are the source of much confusion for many non-patent professionals, including scientists, engineers, physicians, and even lawyers and judges who are not specialists in patent law.

A US patent is enforceable only in its home country. However, international agreements such as the Patent Cooperation Treaty provide some degree of uniformity between the patent laws of various countries [20]. These agreements also provide for easier pursuit of patent protection on a new technology in multiple jurisdictions. Nevertheless, the courts of each country must interpret the particular law of their own jurisdiction, and all of these factors combined yield different end results for patent challenges across the world [21,22].

The Court of Appeals for the Federal Circuit (CAFC) is the highest patent specialist court in the US. In fact, this court of appeals has unique authority among all the US courts of appeals. Its decisions are binding precedents throughout the US on patent law matters, whereas the other courts of appeals are binding only for their own geographic jurisdictions. Thus, the only superseding authorities are the Supreme Court and Congress. Furthermore, because Supreme Court review is discretionary, CAFC decisions are often the final word on patent law matters [23]

('Myriad') [3] included both method and product claims, which are affected differently by recent court decisions. On 20 March 2012, a unanimous Supreme Court held in Prometheus v. Mayo ('Prometheus') [4] that Prometheus Laboratories' claims to methods of optimizing the dosage of drugs to treat gastrointestinal autoimmune diseases do not qualify as patentable subject matter under section 101 of the Patent Act (the section that specifically deals with what types of subject matter are eligible for patenting) [5].

Prometheus itself is not a gene patent case but has important implications for gene patents, especially claims of the method type. Thus, shortly thereafter, the Supreme Court issued a 'GVR order' for the Myriad case [3] in light of their decision in Prometheus. A GVR order means that in one swift motion, the Supreme Court (1) granted review of the Myriad case, (2) vacated the decision of the court of appeals below, and (3) remanded the case back to the court of appeals for further review in light of the new Supreme Court decision in Prometheus. The justices apparently believe that the court of appeals might find something relevant to the Myriad case within their analysis of Prometheus. Unfortunately, the patent practitioner community is having a difficult time figuring out what that might be, and therefore a large number of biotechnology patents currently stand in limbo [6]. One reporter wrote, 'It is apparently possible to split legal hairs endlessly over whether DNA is or is not patentable, and these patent claims will certainly be fought to the bitter end, as they are a crucial test case for future decisions' [1].

The Court of Appeals for the Federal Circuit (CAFC) is the US court that hears first appeals on all US patent cases. In March 2010, in the Myriad case, a Federal
District Court judge invalidated all of Myriad Genetics' challenged gene patents. Myriad appealed to the CAFC, and in July 2011 the CAFC announced its decision. That decision partially reversed that of the District Court on many of Myriad's challenged 'isolated DNA' product claims, finding them to encompass legitimately patentable subject matter under section 101 of the Patent Act.

But the plaintiffs (the patent challengers) actually won some very important aspects of the case at the CAFC level the first time. Although the CAFC decision upheld many of the product claims at issue, it also affirmed the lower court's invalidation of Myriad's broad method claims. This part of the decision has received little fanfare. A closer look suggests that disproportionately heightened public concern over isolated DNA product claims, although understandable, is misplaced and that we should keep our eye on the right ball - in this case, the outcome of deliberations regarding the eligibility of the method claims.

A representative method claim from Myriad's US Patent No. 6,033,857 is:

Claim 1: A method for identifying a mutant $B R C A 2$ nucleotide sequence in a suspected mutant $B R C A 2$ allele which comprises comparing the nucleotide sequence of the suspected mutant BRCA2 allele with the wild-type $B R C A 2$ nucleotide sequence, wherein a difference between the suspected mutant and the wild-type sequences identifies a mutant $B R C A 2$ nucleotide sequence. [our emphasis]

The CAFC decision rejected these method claims to comparing BRCA2 sequences on the basis that they 
recite 'nothing more than abstract mental steps.' The Supreme Court has previously said that the only recognized exceptions for patent eligibility, at the most basic level (section 101), are 'laws of nature, physical phenomena, and abstract ideas' [7]. Further guidance for determining when claims cover abstract ideas is scant, but methods comprising purely mental steps such as comparing have consistently been found to encompass abstract ideas [8].

When the Supreme Court decided Prometheus, they said that the claims in dispute, which describe a process (or method) of adjusting drug dosage based on metabolite levels, essentially monopolized laws of nature. The relevant laws of nature, according to the court, are the 'relationships between concentrations of certain metabolites in the blood and the likelihood that a dosage of a thiopurine drug will prove ineffective or cause harm' They asked, 'do the patent claims add enough to their statements of the correlations to allow the processes they describe to qualify as patent-eligible processes that apply natural laws?' [9].

Their unanimous answer was that in this case, the aspects of the claims related to application of the law of nature were 'not enough'. Supreme Court decisions are supposed to guide the lower judiciary and lawyers' expectations for subsequent cases, but it is unclear just how to determine whether similar method claims might pass muster under this analysis. That is, how can the Supreme Court's reasoning be applied to other patents to reasonably predict how much is enough? Without further guidance from the Supreme Court, method claims regarding specific genes are now in a tenuous position.

Moreover, the Supreme Court's analysis discusses that the steps of the claimed process are 'well understood, routine, conventional activity'. This sounds to the patent community suspiciously close to a line of argument about novelty or obviousness rather than about proper subject matter eligibility [10]. Alternatively, it might suggest that the Supreme Court is insisting that novelty and obviousness have some relevance to subject matter eligibility. The CAFC has now asked the parties to submit supplemental briefs explaining how the Prometheus ruling applies to the Myriad claims.

\section{Isolated DNA molecules}

Although broad method claims may have the potential for widespread effects on the genetic community, patent claims on any particular isolated DNA molecule, although common, are becoming less relevant in diagnostics because of advancing technology. Next-generation sequencing platforms generally avoid the need to isolate any particular DNA molecule. It is therefore unlikely that sequencing would infringe claims requiring DNA isolation, including a claim to an isolated DNA having any particular sequence. We are not the first to propose that whole-genome sequencing probably infringes patents involving genetic technologies to a lesser extent than widespread beliefs might suggest [11].

There is further reason to be less concerned about product claims that focus on isolated DNA. Owing to the dissemination of genetic knowledge and requirements of latter sections of the Patent Act (Box 1), it is becoming more difficult to receive allowance from the patent office on DNA claims. If the sequence has been published, such as in the reference human genome, the corresponding DNA molecules become far less novel and non-obvious; novelty and non-obviousness are both additional requirements for patenting. Moreover, the patents having DNA claims in the Myriad case will begin to expire in 2014, and many other patents covering DNA molecules with naturally occurring sequences will likewise expire in the next decade.

The Supreme Court has stated that Congress intended patentable subject matter to 'include anything under the sun that is made by man' [12], and it is indisputable that a PCR product fits that description. A gene as it exists in nature, by contrast, is certainly not 'made by man', and enforcement of the Myriad method claim discussed above could arguably monopolize the BRCA2 gene to some extent. To be fair, holders of such gene patents have generally not used them against basic research activities. One only has to search 'BRCA' in literature databases to realize that Myriad has not asserted its patents against publicly funded basic research endeavors. Nevertheless, these claims have been asserted in the setting of clinical research for a fee by Myriad Genetics, and indiscriminate assertion of such patents is always a possibility.

Although granting patent protection related to a naturally occurring gene is both fundamentally problematic to some and increasingly dubious from the standpoint of novelty and non-obviousness to others, the development of new, non-natural DNA sequences through synthetic biology is a field in which full public disclosure in patent applications is highly desirable and warrants rewarding the inventor with a monopoly. So for synthetic DNA technology, it should be permissible to claim a DNA having a truly novel sequence, because there is no DNA with that sequence found in nature.

\section{More medical diagnostic claims: mental steps and abstract concepts}

The Myriad case has received the most attention in recent popular media, and Prometheus is now running a close second. But there is a third relevant contemporary biotechnology case involving diagnostic methods claims in which the challenge is focused solely on whether the subject matter is patent eligible. The common thread among these cases is the primary issue argued - that the 
methods claims are 'abstract'. A judicially created doctrine forbids patenting of abstract principles [8].

It can be very challenging for the courts to determine where to draw the line between a purely abstract idea that effectively 'preempts broadly the use of any natural correlation' and a patentable application of that concept, such as a specific biochemical test [13]. For example, well-known methods used to administer prescription drugs and test blood have been found to involve 'transformations' of body chemistry, which moves the method out of the abstract category [14].

Classen Immunotherapies, Inc. v. Biogen Idec ('Classen'), like Prometheus, is also not specifically about gene patents but involves conceptually similar method claims [13]. In this case, the Classen patents cover methods for correlating vaccination schedules with later development of immune-mediated diseases. Some of the claims are very broad. In fact, Judge Moore dissented from the other two judges in the ruling, and she read the claims to preempt the scientific method itself. The basic steps of the method are:

1 screening information on immunization schedules and the occurrence of chronic immune-mediated disease,

2 comparing the results from different vaccination schedules and identifying the lower risk schedule, and

3 administering the vaccine on that lower risk schedule.

The CAFC invalidated some claims that only include steps of screening and comparing vaccination schedules for correlations with later development of immunemediated disorders. However, once again the 'administering' step takes the claims out of the abstract category according to the majority of judges. The court allowed claims that included an additional step of administering vaccinations, solely because the additional administering step transforms the method from an abstract concept to a patent-eligible application of that concept. The striking effect, as noted by the CAFC, is that a physician might infringe merely by reviewing the literature and then vaccinating on the schedule that seems best to him or her.

A common theme in earlier higher court decisions is that a method claim solely comprising mental steps such as reviewing, comparing, analyzing, screening, selecting, and determining will not stand as eligible to be patented because it is abstract. And even if the claim includes additional non-abstract steps, such as in Classen and Prometheus, it may not stand if it does not meet the requirements of the rest of the Patent Act, such as novelty and non-obviousness.

\section{Novelty and non-obviousness}

Novelty is a question of whether the technology is really new. Obviousness may be found where the 'subject matter as a whole... was obvious to one of ordinary skill in the art... at the time of invention [15]. This is usually an inquiry that involves having experts from each party explain why their party is correct to advise the court on how obvious they think the invention was. This is also a difficult inquiry, but at least the courts are instructed to consider a number of better-defined criteria that come from precedential cases (called Graham factors).

The CAFC and many patent practitioners have expressed frustration over the recent trend of increased reliance on subject matter eligibility arguments (such as whether the patent claim is abstract) rather than novelty or obviousness arguments [16]. The patent community has long struggled to properly convey this important concept - the sections that follow section 101 (Box 1) are meant to provide the real teeth for eliminating objectionable patents. For example, according to a precedential patent office case (affirmed by the CAFC), a claim to the human DNA for protein $\mathrm{X}$ is obvious if the mouse DNA for protein $\mathrm{X}$ was already known in the literature and there was good reason to believe that homologous human DNA existed [17]. The Supreme Court analysis of Prometheus sounds disturbingly similar to an obviousness argument to many patent practitioners [10]. Thus, it is not clear that the present Supreme Court fully understands the distinctions between section 101 and the sections that follow it, which have historically been preferred over section 101 for finding problematic subject matter unpatentable.

A general tenet of US law holds that, where multiple arguments are presented, the court focuses on the clearest and most determinative argument that can decide the case. In the interest of judiciary efficiency, the court does not consider other more difficult issues. It is much easier for judges to explain a decision that invalidates a claim based on arguments that the invention is obvious or because it has already been described in the literature than decisions based on other issues. The Supreme Court and CAFC both previously tended towards that strategy, to avoid addressing the more difficult and more broadly applicable section 101 subject matter question that is designated to Congress. And Congress does act on that responsibility occasionally - the 2011 America Invents Act includes a prohibition on patents covering human organisms [18].

The arguments available under the latter sections of the Patent Act are often much stronger and clearer. In fact, in Classen the CAFC took the unusual additional step of outlining exactly how all of the remaining 'administering' claims would have been successfully defeated under patent rules in other parts of the Act. The most glaring issue was that the literature had completely described a system for comparing vaccination schedules over a decade before Classen tried to patent the method, so the invention lacked novelty and would therefore be invalidated if challenged on that theory. 
In addition, in Classen the CAFC panel specifically admonishes litigants over the lack of arguments based on other parts of the Patent Act, in three separate opinions. All three judges suggest to varying degrees that all of Classen's claims would be invalid if properly challenged. Indeed, even in the Myriad decision the CAFC suggests that arguments under the more stringent sections of the Patent Act would have a much better chance of defeating even the isolated DNA claims.

\section{Other important factors to consider}

Each claim in a patent may stand or fall independently of the other claims. Thus, each claim in a patent must be analyzed separately to determine what it encompasses. The examiners at the patent office are charged to do the same analysis before granting a patent, but as with all human activity, it is inevitable that examiners make mistakes. A safeguard lies in the fact that US patents can be challenged after they are granted on most of the same requirements as for examination.

Secrecy is sometimes an alternative to patenting, but one that conveys less benefit to the public than the protection of technology investment through granting of patents. The public value of the patent system lies in the innovator's duty to fully disclose the patented discovery or invention to the public in return for the limited monopoly granted by a patent. In addition, patents serve to provide security to potential investors in new biotechnologies.

The possibility that privately funded ventures will increasingly resort to secrecy to protect new DNA technologies is substantial and could frustrate progress overall. Some types of technology will not be feasible to protect through secrecy, and those potential ventures may simply be abandoned for lack of confidence in the ability to protect investment. Thus, it can be dangerous to take an all-or-none approach to the patent system and its effects on progress in medical science. Licensing practices are also important in limiting or exacerbating negative effects of patents. In particular, those involved in technology transfer of federally funded university inventions should be careful in appropriate circumstances to maintain policies against exclusive licensing ([19] and Catherine Innes, personal communication).

History is full of examples in which existing law could not keep up with what was happening on the ground. The Homestead Act of 1862 was an official acknowledgement by the US government of the pioneers' land claims, but people were moving west, staking those claims, and occupying the land before the Homestead Act anyway. Likewise, we are probably witnessing significant patent infringement (with regard to all of the now-tenuous method claims) owing to the reality of next-generation sequencing and its widespread adoption. Science forges ahead despite the more broadly drafted method claims, including the myriad large-scale sequencing efforts (pun intended) currently underway at multiple centers. Such efforts are potentially infringing many method patents that may or may not withstand legal challenge according to the Supreme Court's fuzzy analysis of Prometheus. Meanwhile, stakeholders will benefit from considering what activities are truly preempted by specific types of patent claims.

Finally, it is important to remember the central intent of the US patent system, which is not primarily as a generator of revenue but rather to 'promote the progress of science and useful arts'. Broad patent claims covering diagnostic methods should be a greater concern for proponents of unencumbered scientific exploration and medicine than the 'isolated DNA' product claims more commonly associated with the term 'gene patent'. The medical and genetic communities should pay attention to what really matters.

Competing interests

The authors declare that they have no competing interests.

\section{Author details}

${ }^{1} 6628$ Ridge Run Ct. Clemmons, NC 27012, USA. ²Department of Genetics, University of North Carolina at Chapel Hill, Chapel Hill, NC 27599-7264, USA.

Published: 29 June 2012

\section{References}

1. Brice P: Myriad retains BRCA gene patents in latest legal ruling. phg foundation, 5 August 2011 [http://www.phgfoundation.org/news/9422/]

2. Associated Press: High court throws out human gene patents. Yahoo News, 26 March 2012 [http://news.yahoo.com/high-court-throws-human-genepatents-161634977.html]

3. United States Court of Appeals for the Federal Circuit: Association for Molecular Pathology et al. v. USTPO et al. Fed Cir 2011 [http://www.cafc.uscourts.gov/images/stories/opinions-orders/10-1406.pdf]

4. Supreme Court of the United States. Syllabus: Prometheus v. Mayo. 2012 [http://www.supremecourt.gov/opinions/11pdf/10-1150.pdf]

5. United States Patent and Trademark Office: 35 U.S.C. 101 Inventions Patentable. In: Manual of Patent Examining Procedure. Washington, DC: USPTO; 2010 [http://www.uspto.gov/web/offices/pac/mpep/documents/ appxl_35_U_S_C_101.htm]

6. Brinckerhoff C: Puzzled by Prometheus. PharmaPatents blog 24 May 2012 [http://www.pharmapatentsblog.com/2012/05/24/puzzled-by-prometheus/] 7. Diamond v. Diehr, 450 U.S. 175 (1981).

8. Supreme Court of the United States: Syllabus: Bilski v. Kappos. 2010 [http://www.supremecourt.gov/opinions/09pdf/08-964.pdf]

9. Conley J, Williams A: Prometheus Patents Struck Down 9-0: Mayo Collaborative Services v. Prometheus Laboratories, Inc. Analysis. Genomics Law Report 21 March 2012 [http://www.genomicslawreport.com/index.php/2012/03/21/ prometheus-patents-struck-down-9-0-mayo-collaborative-services-vprometheus-laboratories-inc-analysis/]

10. Quinn G: Killing Industry: The Supreme Court Blows Mayo v. Prometheus. IP Watchdog 20 Mar 2012 [http://www.ipwatchdog.com/2012/03/20/ supreme-court-mayo-v-prometheus/id=22920/]

11. Holman C: Debunking the myth that whole-genome sequencing infringes thousands of gene patents. Nat Biotechnol 2012, 30:240-244.

12. Diamond v. Chakrabarty, 447 U.S. 303 (1980).

13. United States Court of Appeals for the Federal Circuit: Classen Immunotherapies, Inc. v. Biogen Idec. Fed Cir 2011 [http://www.cafc.uscourts. gov/images/stories/opinions-orders/06-1634-1649.pdf]

14. United States Court of Appeals for the Federal Circuit: Prometheus v. Mayo. 
Fed Cir 2010

[http://www.cafc.uscourts.gov/images/stories/opinions-orders/08-1403.pdf]

15. United States Patent and Trademark Office: 35 U.S.C. 103 Conditions for patentability; non-obvious subject matter. In Manual of Patent Examining Procedure. Washington, DC: USPTO; 2010 [http://www.uspto.gov/web/ offices/pac/mpep/documents/appxl_35_U_S_C_103.htm]

16. United States Court of Appeals for the Federal Circuit: Classen Immunotherapies, Inc. v. Biogen Idec. Fed Cir 2011 'Additional Views' by Judge Rader

17. United States Court of Appeals for the Federal Circuit: in re Kubin. Fed Cir 2009 [http://www.cafc.uscourts.gov/images/stories/opinions-orders/08-1184.pdf]

18. United States House of Representatives Committee on the Judiciary: America Invents Act of 2011

[http://judiciary.house.gov/issues/issues_patentreformact2011.html]

19. Merrill SA, Mazza AM: Reaping the Benefits of Genomic and Proteomic Research: Intellectual Property Rights, Innovation, and Public Health. Report of the National Research Council of the National Academies. Washington: National Academies Press, 2006.
20. United States Patent and Trademark Office: The Patent Cooperation Treaty (PCT). In Manual of Patent Examining Procedure. Washington, DC: USPTO; 2010 [http://www.uspto.gov/web/offices/pac/mpep/documents/1800_1801.htm]

21. Huys I, Van Overwalle G, Matthijs G: Gene and genetic diagnostic method patent claims: a comparison under current European and US patent law. Eur J Hum Genet 2011, 19:1104-1107.

22. Ridley A, Nicol D: Is there still a place for gene patents in Australia? Implications of recent United States and European case law. J Law Med 2011, 19:282-299.

23. Federal Judicial Center: History of the Federal Judiciary: U.S. Court of Appeals for the Federal Circuit

[http://www.fjc.gov/history/home.nsf/page/courts_coa_circuit_fc.html]

doi:10.1186/gb-2012-13-6-161

Cite this article as: Dobson AW, Evans JP: Gene patents in the US - focusing

on what really matters. Genome Biology 2012, 13:161. 